\title{
PLANT DIVERSITY-ENVIRONMENT RELATIONSHIPS IN XERIC GRASSLANDS OF NORTH-EASTERN ROMANIA
}

\author{
MARDARI, C. ${ }^{{ }^{*}}-$ TĂNASE, C.

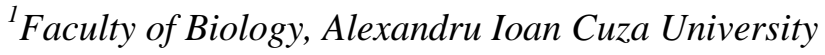 \\ Carol I 20A, Iaşi 700505, Romania \\ (phone: +04-0-232-201373; fax: +04-0-232-201385) \\ ${ }^{*}$ Corresponding author \\ e-mail: constantin.mardari@uaic.ro; mardariconstantin@yahoo.com. \\ (Received $5^{\text {th }}$ Sep 2015; accepted $13^{\text {th }}$ Nov 2015)
}

\begin{abstract}
Dry grasslands are plant communities with major importance for biodiversity. In this study, xeric grasslands of the order Festucetalia valesiacae from North-Eastern Romania were analyzed, in 45 nested series, at seven grain sizes $\left(0.0001-100 \mathrm{~m}^{2}\right)$, sampled in 5 plant communities within above mentioned phytosociological unit. The aim was to test the relative importance of different environmental factors on species richness ( $\alpha$-diversity) and species turnover ( $\beta$-diversity), the last one expressed as the exponent of the power-law species-area relationship, and to detect which is the influence of spatial scale on diversity-environment relationship. Generalized linear models were used to assess the relative importance of predictors in shaping diversity in all seven spatial scales. The results showed that diversityenvironment relationships were dependent on the scale of analysis, different factors being influential at different spatial scales. Local environmental conditions and land use practices were more related to species richness while general soil characteristics explained a larger proportion of spatial species turnover. In conclusion, diversity-environment relationships in the xeric grasslands from North-Eastern Romania are scale dependent, with local factors more important at small spatial scales and soil parameters more important for larger scales.
\end{abstract}

Keywords: patterns, scale dependence, species richness, species turnover, Festucetalia valesiacae

\section{Introduction}

Dry grasslands (Festuco-Brometea) are preponderantly semi-natural communities of herbaceous plants dominated by Poaceae species, with a major importance for biodiversity in Europe and, consequently, of great conservation value (De Vries et al., 2002; Cremene et al., 2005). Most of them evolved under the combined effects of environmental conditions and traditional land use (Janisová et al., 2011). Although in the past xerophytic grasslands had a great extension in the temperate regions of Europe, particularly in the eastern and central parts of the continent, the change in the land use, intensification and expansion of agriculture practices led to their large scale fragmentation (Zulka et al., 2014). However, despite they are threatened plant communities, at small spatial scales (up to $10 \mathrm{~m}^{2}$ ) dry grasslands represents the most species rich plant communities (Wilson et al., 2012; Dengler et al., 2012). As an example of their extraordinary diversity one can be mentioned the semi-dry grasslands from Transylvania (Romania) which have the world record of vascular plants diversity at two spatial scales (Dengler et al., 2014; Turtureanu et al., 2014). Another examples of extraordinary species rich grasslands are in Ukraine (Roleček et al., 2014) or in CzechSlovak territory (Merunková et al., 2012). In Romania, in their floristic composition there are numerous rare or threatened species inserted in the appendices of Habitats Directive of the European Union (1992). Also, the dry grasslands habitats (as 6240* 
Sub-pannonic steppe grasslands and $62 \mathrm{C} 0 *$ Ponto-Sarmatic steppes) are considered as threatened (Gafta and Mountford, 2008) and protected by national legislation.

Diversity patterns in dry grasslands can be determined by local - water and nutrient availability, topography, management, disturbances and biotic interactions (Reitalu et al., 2012), regional factors as the climate (Maalouf et al., 2012) or landscape heterogeneity (Pausas and Austin, 2001). Frequently, species richness in dry grasslands was related to their productivity, the relationship differing from unimodal in high productive grasslands to simple positive in grasslands with lower productivity where is limited by water availability (Dengler et al., 2014). Diversity is also controlled by other factors as nutrient availability, which is significantly influenced by soil $\mathrm{pH}$, temperature and salinity (Dengler et al., 2014). Since local or regional factors could co-vary with other ecological factors, their singular effect is difficult to assess. This situation is known for light (solar radiation) and temperature which are associated to a reduction in water availability while the decrease in water availability is known to produce decrease in plant diversity (Pausas and Austin, 2001). Land use (as a type of disturbance) can have an important role in the maintenance of diversity in ecosystems by reducing competitive exclusion (Middleton, 2013). In fact high species richness is correlated with intermediate disturbance levels as long as other parameters are constant. For instance the response of species richness to traditional practices (mowing) was positive in lowintensity managed grasslands from Transylvania (Turtureanu et al., 2014). Moreover, a weak positive response of species richness to grazing was maintained when (lowintensity) grazed versus unused grasslands were compared (Turtureanu et al., 2014); however, the trend change as grazing intensity increases (Klimek et al., 2007). Abandonment of traditional practices produces a decline of species richness as a result of litter accumulation or dominance of few adapted species (Pykälä et al., 2005; Enyedi et al., 2008). In this perspective, field management should represent an important component of conservation strategies developed in order to maintain species richness in agricultural landscapes.

From another perspective, species richness from a certain region depends on numerous factors and the effect of ecological factors or management type on species richness is scale-dependent (Dengler, 2009a; Giladi et al., 2011; Reitalu et al., 2012; Siefert et al., 2012; Turtureanu et al., 2014; Wanner et al., 2014). In this respect, species-area relationships can be used in order to investigate plant diversity patterns across scales (Dengler, 2008; Dengler, 2009b; Wilson et al., 2012) and their relationships with above mentioned factors, using the $z$-values of the power-law function $\mathrm{S}=\mathrm{cA}^{\mathrm{z}}(\mathrm{S}=$ species richness, $\mathrm{A}=$ area), values which can be regarded as a measure of spatial turnover or $\beta$-diversity (Drakare et al., 2006; Turtureanu et al., 2014). Moreover, species-area relationships' parameters also differ between community types (Dolnik and Breuer, 2008).

In order to detect patterns of plant diversity in the xeric grasslands from NorthEastern Romania, the multi-scale sampling in almost all plant communities from Festucetalia valesiacae phytosociological order in this area was used. The aim of the study was to test if there is, and what is the influence of spatial scale $\left(0.0001 \mathrm{~m}^{2}-100\right.$ $\mathrm{m}^{2}$ ) on the relative importance of different environmental factors on $\alpha$-diversity (species richness) and $\beta$-diversity (z-values power-law function $\mathrm{S}=\mathrm{cA}^{\mathrm{z}}$ ) of these in the xeric grasslands in the above mentioned region. Anoher objective was to observe if both species richness and species turnover are dependent on the plant community type. 


\section{Material and methods}

\section{Study area}

The study area (Fig. 1) is situated in the North-Eastern part of Romania (46 $30^{\circ}$ $47^{\circ} 40^{\prime} \mathrm{N}$ and $26^{\circ} 40^{\prime}-28^{\circ} 00^{\prime} \mathrm{E}$ ) and includes two geographical sub-divisions of the Moldavian Plateau: Moldavian Plain (with mean altitudes of 150-200 m.a.s.l.) and Central Moldavian Plateau (with mean altitudes of 150-250 m.a.s.1.). The general plateau character was modified due to erosion phenomenon in a fragmented relief, with long hills ranges, north-west to south-east oriented and wide valleys. The climate is temperate continental, with cold winters and very hot summers, with frequent droughts; mean annual temperatures varies from 9 to $10{ }^{\circ} \mathrm{C}$, mean annual precipitation ranges from 400 to $600 \mathrm{~mm} / \mathrm{m}^{2}$. Geology is represented by a fundament of Precambrian crystalline rocks covered by Sarmatic and Pliocene deposits - limestone, marls, clays, gravels and sands (Chifu et al., 2006). The main soil types in the region are mollisols in the forest-steppe from eastern and south-eastern part of the Moldavian Plateau and, in a lower extent, chernozems in the north-eastern part. The landscape is mainly agricultural, with grasslands patches maintained only on accentuated slopes, impropriate for agriculture, and isolated oaks forests at higher elevations (over 180-200 m.a.s.l.).

From a phytogeographical perspective, a part of the study area is included in the Euro-Siberian floristic region, with the Moldavian Plateau Province and Central Moldavian Plateau district defined by some endemic (Centaurea simonkaiana, Rubus subvilicaulis), Pontic (Bulbocodium versicolor) or Balkanic species (Tilia tomentosa). The other part belong to the Irano-Turanian floristic region with the Balkanic-Moesian Province and Jijia district characterized by several Pontic (Erysimum exaltatum, Schivereckia podolica), Pontic-Mediterranean (Ajuga chamaepitys subsp. ciliata, Scorzonera hispanica), Pontic-Balkanic (Allium atropurpureum, Linum tauricum) elements (Chifu et al., 2006). According to Habitats Directive of the European Union (1992), almost all studied territory is considered as part of the continental biogeographical region and only a small, southern area, is included in the steppic biogeographical region.

\section{Field sampling}

Only grasslands within Festucetalia valesiacae order, which are more xerophytic, represent the subject of the present study. A total of 45 nested-plot series were sampled in the most typical plant communities within the above mentioned phytosociological order within Festuco-Brometea class (Coldea et al., 2012): Jurineo arachnoideae Stipetum lessingianae (Dobrescu 1974) Chifu, Mânzu et Zamfirescu 2006, Taraxaco serotinae - Festucetum valesiacae (Burduja et al. 1956) Sârbu, Coldea et Chifu 1999, Taraxaco serotinae - Bothriochloetum iscahaemi (Burduja et al. 1956) Sârbu, Coldea et Chifu 1999, Agropyro pectinati - Stipetum capillatae (Burduja et al. 1956) Chifu, Mânzu et Zamfirescu 2006 and Thymo pannonici - Chrysopogonetum grylli Doniţă et al. 1992) - see Appendix 1 for vegetation data and Appendix 2 for vegetation classification. Only one plant community (Artemisio austriacae - Poaetum bulbosae Pop 1970 was not sampled because it includes in fact pastures of Festuca valesiaca degraded by excessive grazing and erosion (Coldea et al., 2012).

Sampling was carried out in homogeneous vegetation stands, in $100 \mathrm{~m}^{2}$ squareshaped plots. In two opposite corners of these $100 \mathrm{~m}^{2}$ plots were delimited two $10 \mathrm{~m}^{2}$ subplots and, after that, $1 \mathrm{~m}^{2}, 0.1 \mathrm{~m}^{2}, 0.01 \mathrm{~m}^{2}, 0.001 \mathrm{~m}^{2}$ and $0.0001 \mathrm{~m}^{2}$ subplots in the 
centre of the next larger plot (Dengler, 2009a). Only vascular plant species were recorded using "any-part system" (Dengler, 2008). Probably drought, high temperatures and a very low cover of rocks and stones are the main factors causing the almost zero cryptogam diversity. Plants nomenclature follows Ciocârlan (2000).

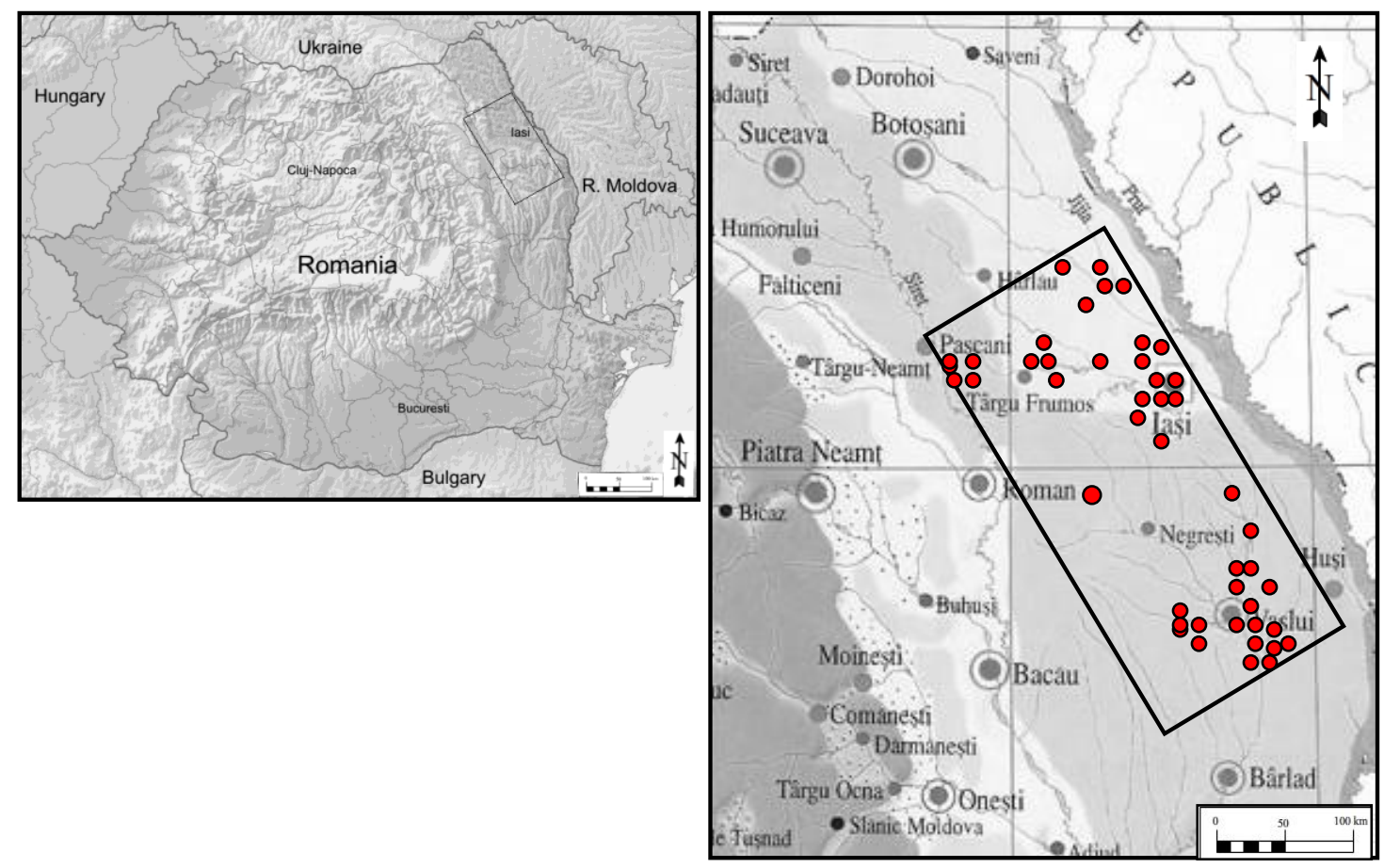

Figure 1. Map of the study area presenting its geographical position in Romanian territory and spatial distribution of the nested-plot series

\section{Environmental variables}

In order to analyze the effect of environmental parameters on dry grasslands diversity, climatic, soil and management regime variables were used (Table 1). The climatic variables (mean annual precipitation, mean annual temperature, minimum temperature of the coldest month, maximum temperature of the warmest month and annual temperature range) were extracted from the WorldClim database (Hijmans et al., 2005).

Ellenberg indicator values (Ellenberg et al., 1992) - unweighted means - for soil reaction and nitrogen were used as surrogates to analyze the effect of these environmental parameters on dry grasslands diversity. Although Ellenberg indicator values are based on expert knowledge, on species co-occurrence patterns and are not independent of local processes (Chytry et al., 2003), it was showed their usefulness when single vegetation types was studied (Wamelink et al., 2002). Nevertheless, vegetation and plant preferences for certain ranges of ecological factors are often (a great number of vegetation-environment relationship articles) used to characterize terrestrial ecosystems because they integrate local ecological processes in a more comprehensible manner than any other factors and can also be used to identify certain soil or climate patterns. For the smaller spatial scales $\left(0.0001,0.001,0.01,0.1,1 \mathrm{~m}^{2}\right)$ the values of the Ellenberg indicator values for $10 \mathrm{~m}^{2}$ were used. The general aspect 
and slope for each $100 \mathrm{~m}^{2}$ plots were recorded and used to calculate the heat load index (Olsson et al., 2009). Also, geographic coordinates and altitude were registered and used for all investigated spatial scales. Note that altitudes values were not measured at the same spatial scale as diversity. Management regime in these xeric grasslands was classified as "mown" (M, 10 sites), "grazed" (G, 23 sites) and "unused" (U, 12 sites) according to the general vegetation appearance, animals presence during sampling and information from local people. It was coded using dummy variables (Turtureanu et al., 2014).

Table 1. Environmental data (means - unweighted means for Ellenberg indicator values, standard deviations, minimum and maximum) used in the analysis of $\alpha$-diversity and $\beta$ diversity at $100 \mathrm{~m}^{2}(n=45)$.

\begin{tabular}{c|c|c|c|c|c}
\hline Variable & Abbreviation & Mean & SD & Minimum & Maximum \\
\hline Altitude (m.a.s.l.) & Alt & 182.11 & 35.92 & 110 & 247 \\
Annual precipitation $(\mathrm{mm})$ & Prec & 553.30 & 13.57 & 520 & 581 \\
$\begin{array}{c}\text { Annual mean temperature } \\
\text { Minimum temperature of } \\
\text { the coldest month }\left({ }^{\circ} \mathrm{C}\right)\end{array}$ & Temp & 9.33 & 0.42 & 8.32 & 10.11 \\
$\begin{array}{c}\text { Maximum temperature of } \\
\text { the warmest month }\left({ }^{\circ} \mathrm{C}\right)\end{array}$ & Tmin & -7.09 & 0.37 & -8.00 & -6.30 \\
$\begin{array}{c}\text { Temperature annual range } \\
\left({ }^{\circ} \mathrm{C}\right)\end{array}$ & Trmax & 26.21 & 0.51 & 24.80 & 27.10 \\
$\begin{array}{c}\text { Heat load index } \\
\text { Ellenberg indicator values } \\
\text { for soil reaction }\end{array}$ & Hload & -0.10 & 0.39 & -1.00 & 0.84 \\
$\begin{array}{c}\text { Ellenberg indicator values } \\
\text { for soil nitrogen }\end{array}$ & EIV-R & 6.93 & 0.28 & 6.30 & 7.60 \\
\hline
\end{tabular}

\section{Statistical analysis}

$\alpha$-Diversity (species richness) and $\beta$-diversity (species richness turnover) environment relationships were modeled for each of the seven scales $(0.0001,0.001$, $0.01,0.1,1,10$ and $100 \mathrm{~m}^{2}$ ) using generalized linear models (GLMs).

All numeric environmental parameters were prior tested for multi-collinearity (existence of two or more highly correlated parameters) using pairwise Pearson correlations (Appendix 3). Environmental parameters were considered as collinear when $|\mathrm{r}|>0.7$ (Turtureanu et al., 2014). In this way it was highlighted that: the annual mean temperature was highly correlated with minimum temperature of the coldest month (0.92), with maximum temperature of the warmest months (0.99) and annual temperature range (0.78); also minimum temperature of the coldest month had a strong relationship with maximum temperature of the warmest months (0.94) and annual temperature range (0.77). As a result, only annual mean temperature, annual mean precipitation, EIV-R, EIV-N, altitude and heat load were used in further analysis. Spatial autocorrelation was tested for $100 \mathrm{~m}^{2}$ plots. Moran'I test based on a list of 10 distance classes ranging from small to large distances did not detect significant spatial autocorrelations in analyzed data (Appendix 3).

Considering that count data were used, generalized linear models with Poisson distribution were computed, but when overdispersion was tested and detected with the dispersiontest function of AER package in R software (Kleiber and Zeileis, 2014) the negative binomial distribution of errors was assumed. Next, full models with negative 
binomial distribution of errors were constructed from all possible variable combinations. Also, single parameter models (using the most important predictors identified via full models) were used to model $\alpha$ and $\beta$-diversities at the seven analyzed spatial scales. The selection of the best models was made based on corrected Akaike information criterion (AICc), more precisely based on the difference $(\Delta)$ in AICc value of a certain model and minimum AICc value registered (Turtureanu et al., 2014). Only models with $\triangle \mathrm{AICc}<2$ were retained (Turtureanu et al., 2014). Akaike weights were used to assess the probability that a given model is the best in whole set. The relative importance of predictors over all models (ranging from 0 to 1 when a predictor is included in all models) was calculated and only the predictors included in at least half of the models with statistical support were included in single parameter models. All models were computed in R software ( $\mathrm{R}$ Development Core Team, 2013) using the glm.nb function from the MASS package (Ripley et al., 2015). Selection of the best models and of the relative importance of predictors was carried out using the dredge and importance functions from the MuMIn package (Barton et al., 2014).

ß-diversity (expressed as the z-values of the power-law function $S=\mathrm{cA}^{\mathrm{z}}$ )environment relationship was modeled using the same methodology as $\alpha$-diversity. The z-values, (S-space, i.e. untransformed S-values) were estimated by fitting the above power-law function using non-linear regression in the Vegan package (Oksanen et al., 2015) from R software (R Development Core Team, 2013) (0.1-value as starting point (Dengler, 2009b; Turtureanu et al., 2014).

\section{Results}

\section{Plant species diversity}

In all $100 \mathrm{~m}^{2}$ plots $(\mathrm{n}=45)$ a total of 273 taxa were found. Species richness at 100 $\mathrm{m}^{2}$ ranged from 13 to 63 with a mean of $42.4 \pm 11.6$. Values for other spatial scales, for $\alpha$-diversity, $\beta$-diversity as well as for environmental variables, means, standard deviations and ranges are given in Table 4. Some differences in species richness occured when community type was analyzed - the highest average species richness was

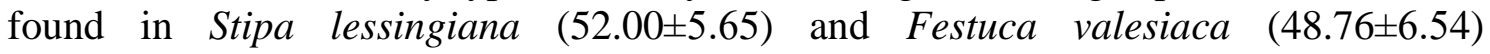
communities and the lowest in Stipa capillata (34.83 \pm 4.49$)$ and Chrysopogon gryllus (22.28 \pm 6.26$)$ communities (Table 2). Land use showed no significant differences of species richness when grazed plots were compared to the unused ones, but only when the mown plots were compared both to grazed and unused ones.

Average value of $\beta$-diversity, calculated in S-space, was $0.194 \pm 0.02$ (Table 4; Appendix 4). Depending on community type, mean values of $\beta$-diversity ranged between $0.169 \pm 0.02$ in Chrysopogon gryllus community to $0.216 \pm 0.01$ in Dichanthium ischaemum community. Land use had not major effects on $z$-values $(0.189 \pm 0.01$ in mown, $0.192 \pm 0.02$ in grazed and $0.193 \pm 0.02$ in unused grasslands). When species richness spatial turnover depending on plant communities was analyzed, the differences were not significant according to Kruskal-Wallis and Mann-Whitney tests (Table 2).

\section{Diversity - environment relationships}

In the xeric grasslands from North-Eastern Romania, the estimates of the relative importance of environmental variables at $0.0001,0.001,0.01,0.1,1,10$ and $100 \mathrm{~m}^{2}$ changed across scales. The land use was an important predictor but significant only at 
larger scales (Table 4, Appendix 5) with negative effects on $\alpha$-diversity, accentuated when grazed versus mown grasslands were compared: $-0.355(\mathrm{p}<0.001)$ at $10 \mathrm{~m}^{2}$, $0.381(\mathrm{p}<0.001)$ at $1 \mathrm{~m}^{2}$. When grazed versus unused grasslands were compared, a slightly positive effect of grazing was detected $(0.130, \mathrm{p}<0.05)$ but only for $1 \mathrm{~m}^{2}$ scale. Heat load had a accentuated negative effect on species richness $-0.248(\mathrm{p}<0.05)$ in 0.01 $\mathrm{m}^{2}$ to $-0.322(\mathrm{p}<0.001)$ in $100 \mathrm{~m}^{2}$ grain. Soil nitrogen content was an important factor especially at $10 \mathrm{~m}^{2}$ scale presenting a positive effect on species richness $(0.207, \mathrm{p}<$ $0.001)$, while altitude influence was insignificant. Soil nitrogen $(-366, \mathrm{p}<0.05)$ was the only predictor showing a unimodal (humpedshaped) relationship only at $10 \mathrm{~m}^{2}$ graind, although all parameters were tested for this type of response. Mean annual precipitations was an important predictor only for the smallest scales (Table 4) with positive effect on species richness $\left(0.218, \mathrm{p}<0.05\right.$ at $0.0001 \mathrm{~m}^{2}$ and $0.200, \mathrm{p}<0.05$ at $0.001 \mathrm{~m}^{2}$ ). Mean annual temperature and soil reaction had not a significant effect on species richness in any scale although a wide range of locations was analyzed. Variation in $\beta$-diversity (Table 4 ) was mostly explained by soil reaction $(-0.141, \mathrm{p}<0.001)$ with a negative effect and soil nutrients with a positive effect $(0.109, \mathrm{p}<0.001)$.

Table 2. Values of species richness and species richness turnover for investigated plant commnities as well as for land use. $P$ values were derived from Kruskal-Wallis non parametric ANOVA. Means followed by the same letter (in columns) do not differ significantly according to Mann-Whitney test ( $p=0.05)$.

\begin{tabular}{l|c|c}
\hline \multicolumn{1}{c|}{ Community type } & $\boldsymbol{\alpha}$-diversity & $\boldsymbol{\beta}$-diversity \\
\hline Jurineo arachnoideae - Stipetum lessingianae & $48.76 \pm 6.54^{\mathrm{a}}$ & $0.196 \pm 0.01^{\mathrm{a}}$ \\
Taraxaco serotinae - Festucetum valesiacae & $52.00 \pm 5.65^{\mathrm{a}}$ & $0.177 \pm 0.01^{\mathrm{ab}}$ \\
Taraxaco serotinae - Bothriochloetum iscahaemi & $44.00 \pm 5.52^{\mathrm{ab}}$ & $0.216 \pm 0.01^{\mathrm{a}}$ \\
Agropyro pectinati - Stipetum capillatae & $34.83 \pm 4.49^{\mathrm{bc}}$ & $0.192 \pm 0.02^{\mathrm{ab}}$ \\
Thymo pannonici-Chrysopogonetum grylli & $22.28 \pm 6.26^{\mathrm{c}}$ & $0.169 \pm 0.01^{\mathrm{b}}$ \\
$p$ (Kruskal-Wallis) & $<0.001$ & 0.00015 \\
\hline \multicolumn{1}{c|}{ Land use type } & & \\
\hline Mown & $52.00 \pm 7.88^{\mathrm{a}}$ & $0.189 \pm 0.01^{\mathrm{a}}$ \\
Grazed & $40.91 \pm 10.28^{\mathrm{b}}$ & $0.192 \pm 0.02^{\mathrm{a}}$ \\
Unused & $38.25 \pm 13.73^{\mathrm{b}}$ & $0.193 \pm 0.02^{\mathrm{a}}$ \\
$p$ & 0.03 & $n . s$. \\
\hline
\end{tabular}

Table 3. Relative importance of predictors (summed Akaike weights in all models in which a variable was included) used for modeling $\alpha$-diversity $(0.0001,0.001,0.01,0.1,1,10$ and 100 $\left.\mathrm{m}^{2}\right)$ and $\beta$-diversity ( $z$-values across all scales). Relative importance of predictors equal or higher than 0.5 is highlighted.

\begin{tabular}{l|c|c|c|c|c|c|c|c}
\hline $\begin{array}{c}\text { Diversity } \\
\text { parameter }\end{array}$ & Prec & Tmean & $\begin{array}{c}\text { EIV- } \\
\text { R }\end{array}$ & $\begin{array}{c}\text { EIV- } \\
\text { N }\end{array}$ & Alt. & Hload & G vs M & G vs U \\
\hline $0.0001(\mathrm{n}=90)$ & $\mathbf{0 . 5 0}$ & 0.28 & 0.26 & 0.25 & 0.37 & 0.27 & 0.26 & 0.27 \\
$0.001(\mathrm{n}=90)$ & $\mathbf{0 . 5 0}$ & 0.38 & 0.24 & 0.25 & 0.30 & 0.38 & $\mathbf{0 . 7 5}$ & 0.36 \\
$0.01(\mathrm{n}=90)$ & 0.26 & 0.28 & 0.25 & 0.26 & $\mathbf{0 . 6 5}$ & $\mathbf{0 . 6 2}$ & $\mathbf{0 . 8 5}$ & 0.32 \\
$0.1(\mathrm{n}=90)$ & 0.26 & 0.38 & 0.34 & 0.26 & $\mathbf{1 . 0 0}$ & $\mathbf{0 . 9 5}$ & $\mathbf{1 . 0 0}$ & 0.25 \\
$1(\mathrm{n}=90)$ & 0.31 & $\mathbf{0 . 6 7}$ & 0.47 & 0.26 & $\mathbf{1 . 0 0}$ & $\mathbf{0 . 9 9}$ & $\mathbf{1 . 0 0}$ & $\mathbf{0 . 5 2}$ \\
$10(\mathrm{n}=90)$ & 0.28 & 0.24 & 0.34 & $\mathbf{0 . 9 6}$ & $\mathbf{0 . 9 0}$ & $\mathbf{0 . 9 5}$ & $\mathbf{1 . 0 0}$ & 0.26 \\
$100(\mathrm{n}=45)$ & 0.28 & 0.36 & 0.39 & 0.46 & $\mathbf{0 . 5 8}$ & $\mathbf{0 . 8 6}$ & $\mathbf{1 . 0 0}$ & 0.24 \\
$z(\mathrm{n}=45)$ & 0.31 & $\mathbf{0 . 9 5}$ & $\mathbf{0 . 7 3}$ & $\mathbf{0 . 9 0}$ & 0.46 & 0.20 & 0.28 & 0.33 \\
\hline
\end{tabular}




\section{Discussion}

The study provides first insights into the factors driving the variation in species richness and species richness turnover in the xeric grasslands within Festucetalia valesiacae phytosociological unit from North-Eastern Romania. It highlighted the role of land-use history and environmental characteristics in modelling the species richness of these dry grassland. Local environmental features and land use practices were more related to species richness while general soil conditions explained a larger proportion of species richness turnover. The diversity-environment relationships turned to be positive or negative, sometimes unimodal, depending on the ecological factor, and, generally, are consistent with other studies (Turtureanu et al., 2014; Wanner et al., 2014) in which grasslands diversity was approached in the context of more or less wider lengths of environmental gradients.

\section{$\alpha$ and $\beta$-diversity}

The mean species richness of 42.1 (for $100 \mathrm{~m}^{2}$ ) and 29.3 (for $10 \mathrm{~m}^{2}$ ) in the studied xeric grasslands (Festucetalia valesiacae) was relatively low compared to the dry grasslands in other Romanian or European regions. For example, in Transylvania (Dengler et al., 2012), relatively close to the investigated area, the mean values for species richness at same grain sizes was 67.5 (47.5), and, in Central Podolia (Kuzemko et al., 2014) mean species richness was 67 (40.3). This evident difference was due to the fact that the very different plant communities were analyzed; also, in this study the Chrysopogon gryllus community was the most species poor plant community ( 22.3 for $100 \mathrm{~m} 2$ and 15.8 for $10 \mathrm{~m}^{2}$ ) and its species richness drastically decreased overall mean species richness. However, when (more or less) similar plant community type were analyzed the differences were not so evident: for $10 \mathrm{~m}^{2}$ grain the Stipa lessingiana community had a mean species richness of 44.5 in Transylvania compared to 38.8 in Moldova (North Eastern Romania), the Stipa capillata community had the mean species richness of 32.1 in Central Podolia compared to 24.3 in North Eastern Romania or Dichanthium ischaemum community with mean species richness of 37.3 in Central Podolia compared to 27.3 in North Eastern Romania. A possible explanation of the lower species richness in these xeric grasslands could be partially related to the number of species adapted to the stress of severe summer droughts, frequently in this subcontinental area. In addition, between xeric grasslands, represented by isolated patches, species immigration is limited and the chance for local extinctions is increased (Palpurina et al., 2015). Compared to other recent studies conducted un the same area, in this investigation total species richness had higher values: for example in Festuca valesiaca community the species richness (information from romanian authors is available only for $100 \mathrm{~m}^{2}$ ) varied from 31.8 (Blaj, 2003) to 36.6 (Sîrbu, 2003) and 43 (Chifu et al., 2000); for Stipa capillata community total species richness was higher in this approach compared to Blaj (2006) who found a mean of 22.8 species in this community, also for Dichanthium ischaemum community with 42.8 mean species richness in this study compared to 36 in Chifu et al. (2000).

Average value of $\beta$-diversity expressed as the $z$-values of the power law function $S=$ $\mathrm{cA}^{\mathrm{z}}$, calculated in S-space, was 0.192 \pm 0.02 (Table 4; Appendix 4), lower compared to other grasslands from Transylvania - Romania (Dengler et al. 2012; Turtureanu et al., 2014) or to some grasslands in Southern Europe (Chirucci et a., 2006), but higher compared to other dry grasslands in Central Europe (Dolnik and Breuer, 2006). 


\section{Diversity - environment relatioships}

Land use was an important factor shaping the species richness of the studied xeric grasslands, included in almost all models from 0.01 to $100 \mathrm{~m}^{2}$ scales. It had a pronounced negative effect in grazed compared to mown and a low positive effect in grazed compared to unused areas (Table 4). However, there was an increase in species richness in either mown or grazed terrains compared to the unused ones, which is consistent with results from other European dry grasslands where diversity was higher in managed areas (Bąba, 2003; Turtureanu et al., 2014). These results suggest that, in almost all xeric grasslands from North-Eastern Romania, species richness is highest in the low intensity mowed and grazed areas, which is consistent with the intermediate disturbance hypothesis (Grime, 1973). Increase in species richness in low intensity managed grasslands was also emphasized in other studies in Romania (Turtureanu et al., 2014) and Europe (Wanner et al., 2014) and such periodical disturbances are required in order to maintain high diversity in grasslands ecosystems (Bonanomi et al., 2013). These results are consistent with the opinion that landscape-scale processes determine the potential for plant community species richness and local processes within the community determine the local diversity (Pärtel et al., 2005). When meadows versus pastures were compared, a negative effect of grazing on species richness was identified, which could be assigned to the selectivity of grazers for certain species (supporting installation of species with rosettes and prostrate growth forms, affecting the vertical structure and light availability). Also, depending on intensity, grazing can significantly affect diversity, structure or composition of xeric grasslands (Enyedi et al., 2008) by reducing the abundance of dominant species (Klimek et al., 2007). Decrease of diversity in these grazed compared to mown xeric grasslands could be also a result of the modification of suitable micro-sites for forbs species (Jørgensen, 2009) or of the erosion of superficial soil layer (Huhta and Rautio, 1998). Decrease in species richness in unused grasslands could be an effect of natural succession processes, by development of shrubs and young trees alongside infiltration of tall competitive nitrophilous species which can eliminate low-growing typical dry grassland species (Isselstein et al., 2005). Another aspect which could explain the decrease in species richness could be the litter accumulation in abandoned grasslands which could decrease species richness by inhibiting seedling establishment through alteration of light regime and physical obstruction (Bonanomi et al., 2013). A decrease of species richness could also occur probably owing to the higher cover value of grass species and due to the gaps restriction in grassland community after abandonment (Catorci et al., 2013).

Heat load index was a strong negative predictor of species richness (Fig. 2) in dry grasslands from North-Eastern Romania in almonst all investigated scales, results in concordance with findings from the study realized in the dry grasslands from Transylvania (Romania) (Turtureanu et al., 2014). This is probably due to local topography and to the underlying process of decrease in water availability in soil, concomitant with increase of slope and solar radiation, leading to the decline of plant diversity (Moeslund et al., 2013) by filtering the plant species which can grow on these dry sites. Also, high values of the heat load index are specific to the steep slopes which could be affected by erosion, with negative effect on plant species richness (Turtureanu et al., 2014).

The positive effect of soil nitrogen on species richness (only at $10 \mathrm{~m}^{2}$ scale) could be interpreted more like the effect of the complex of soil nutrients since the indicator values for nitrogen availability may be interpreted as an index of general trophic status 
(Ertsen et al., 1998; Schaffers and Sýkora, 2000) or soil fertility (Schwabe et al., 2007). This type of relationship (linear) can be expected in nutrient poor xeric grasslands, compared to higher nutrient levels when species richness is decreasing (Becker and Brändel, 2007). From another perspective, only soil nutrients showed a unimodal relationship in respect to species richness (although all parameters were investigated for this type of response). This could be interpreted as: the increase in soil nutrients up to a certain point could produce an increase in species richness, beyond this point it could produce increased asymmetric competition and dominance of one-two species but with a high competitive ability leading to the exclusion of less competitive species and finally to decrease in species richness. Unimodal relationships between plant species richness and nutrients were also highlighted in other dry grasslands in Europe (Merunková et al., 2014; Turtureanu et al., 2014).

Table 4. Effect of predictors according to their relative importance in single parameter generalized linear models. Abbreviations: Std. coef., standardized coefficients; SE, standard errors; ***<0.001; **<0.01; *<0.05, n.s. - not significant.

\begin{tabular}{|c|c|c|c|c|c|}
\hline $\begin{array}{c}\text { Diversity } \\
\text { parameter }\end{array}$ & Mean \pm SD & Predictor & Std. coef. & SE & $\mathbf{p}$ \\
\hline $0.0001(\mathrm{n}=90)$ & $1.7 \pm 0.7$ & Prec & 0.218 & 0.19 & $*$ \\
\hline \multirow[t]{2}{*}{$0.001(\mathrm{n}=90)$} & $3.07 \pm 1.1$ & Prec & 0.200 & 0.13 & $*$ \\
\hline & & Grazed vs. mown & -0.272 & 0.10 & $*$ \\
\hline \multirow[t]{3}{*}{$0.01(\mathrm{n}=90)$} & $6.2 \pm 2.3$ & Alt & -0.001 & 0.001 & n.s. \\
\hline & & Hload & -0.248 & 0.11 & $*$ \\
\hline & & Grazed vs. mown & -0.244 & 0.08 & $* *$ \\
\hline \multirow[t]{3}{*}{$0.1(\mathrm{n}=90)$} & $12.5 \pm 4.1$ & Alt & -0.002 & 0.0008 & $* *$ \\
\hline & & Hload & -0.302 & 0.07 & $* * *$ \\
\hline & & Grazed vs. mown & -0.343 & 0.06 & $* * *$ \\
\hline \multirow[t]{5}{*}{$1(n=90)$} & $18.7 \pm 6.6$ & Tmean & 0.001 & 0.05 & n.s. \\
\hline & & Alt & -0.002 & 0.0006 & $* * *$ \\
\hline & & Hload & -0.319 & 0.06 & $* * *$ \\
\hline & & Grazed vs. mown & -0.381 & 0.04 & $* * *$ \\
\hline & & Grazed vs. unused & 0.130 & 0.05 & $*$ \\
\hline \multirow[t]{5}{*}{$10(\mathrm{n}=90)$} & $28.9 \pm 9.4$ & $\mathrm{~N}$ & 0.207 & 0.04 & $* * *$ \\
\hline & & $\mathrm{N}^{2}$ & -0.366 & 0.14 & $*$ \\
\hline & & Alt & -0.001 & 0.0005 & $*$ \\
\hline & & Hload & -0.311 & 0.05 & $* * *$ \\
\hline & & Grazed vs. mown & -0.355 & 0.03 & $* * *$ \\
\hline \multirow[t]{3}{*}{$100(\mathrm{n}=45)$} & $42.1 \pm 11.6$ & Alt & -0.0006 & 0.0006 & ns \\
\hline & & Hload & -0.322 & 0.06 & $* * *$ \\
\hline & & Grazed vs. mown & -0.305 & 0.04 & n.s. \\
\hline \multirow[t]{3}{*}{$\mathrm{z}(\mathrm{n}=45)$} & $0.192 \pm 0.02$ & Tmean & 0.095 & 0.03 & $* * *$ \\
\hline & & $\mathrm{R}$ & -0.141 & 0.03 & $* * *$ \\
\hline & & $\mathrm{N}$ & 0.109 & 0.02 & $* * *$ \\
\hline
\end{tabular}

Mean annual precipitations were the only predictor important for species richness in the smallest analyzed spatial scales. Their effect could be interpreted under two facets. First, the severe droughts, which are frequent in the study area, could determine lower species richness at small scales by the influencing the niche 
processes and limiting species suitable sites within these xeric grasslands. Second, the positive effect of precipitations on species richness could indirectly derive from their influence on different biotic (germination process) and abiotic (as soil moisture) factors. The positive effect of soil moisture is concordant with the general opinion that plant diversity typically increase with increasing water availability (Dengler et al., 2014; Pausas et Austin, 2001). Increase in species richness with increase of precipitations was also highlighted in other studies in dry grasslands (Adler and Levine, 2007; Palpurina et al., 2015).

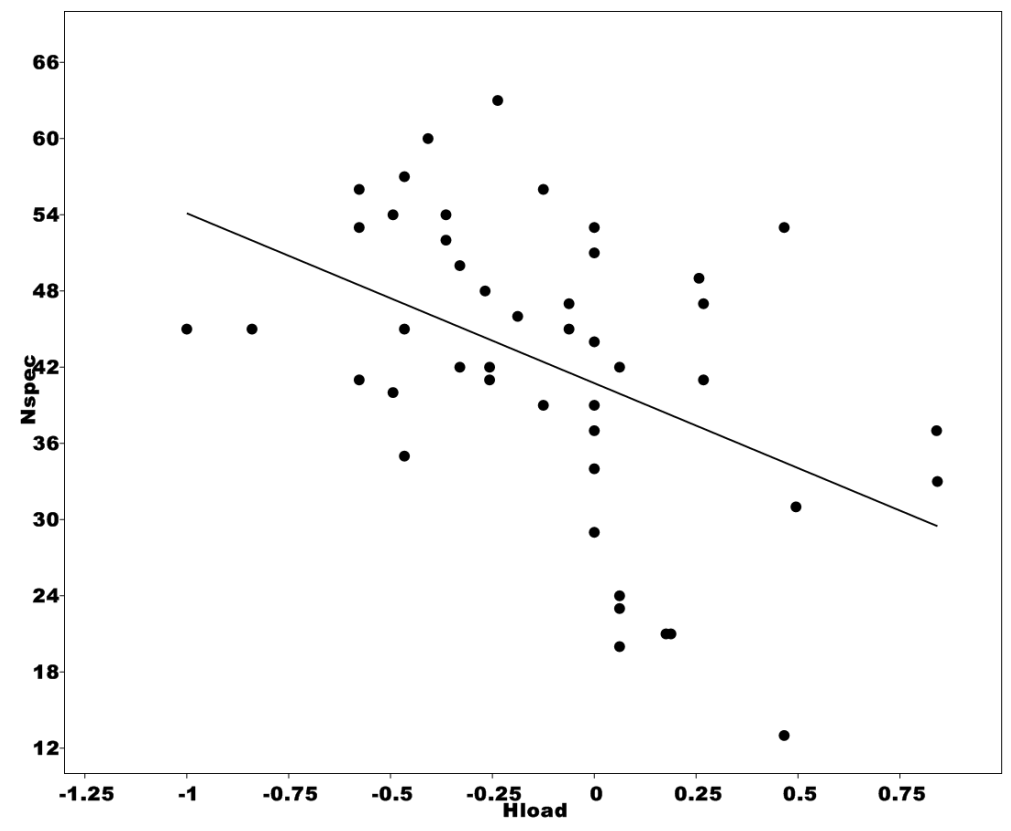

Figure 2. Variation in species richness $\left(100 \mathrm{~m}^{2}\right)$ depending on the heat load index

Soil nutrients and soil reaction (Fig. 3) were the most important factors explaining the species richness turnover ( $\beta$-diversity), meaning that resource driven processes could control the local variation of plant species composition and richness in the studied xeric grasslands. In this particular case, the soil nutrients content displayed a positive relationship: thus, lower $z$-values corresponding to lower nutrients values were associated to a steeper increase in species richness, while higher $z$-values corresponding to higher nutrients content suggested a more gradual increase in species richness. Generally, in studied dry grasslands, increase in nutrients availability positively affected species richness. The steep increase in species richness at small spatial scales could possibly be explained by the different abilities of different plant species to use the fine scale heterogeneous soil resources. Thus, in smaller spatial scales there were few species adapted to exploit soil limiting nutrients, resulting in above ground competition and leading to exclusion of lower height or slower growing species. At larger spatial scales, differentiation in the modalities of exploit soil nutrients permitted coexistence of an increased number of species. Soil reaction had a negative influence on species richness turnover, a steeper increase in species richness was associated with higher values of soil reaction, while a more gradual increase in species richness was associated to lower values of soil reaction. A possible explanation could be that in terrains 
characterized by higher values of soil $\mathrm{pH}$ negatively affect plant species richness at small spatial scales probably due to fewer species adapted to nutrient uptake limitation associated with basic substrates while at larger spatial scales more generalist species for soil $\mathrm{pH}$ can occur (Palpurina et al., 2015).

Taking into account the plant community type, among all studied grasslands, only Thymo pannonici - Chrysopogonetum grylli community (with the lowest values) significantly differed in respect to species richness turnover. Compared to the other communities, there was a steeper increase in species richness in Thymo pannonici Chrysopogonetum grylli at small spatial scales compared to larger ones. A possible explanation could be related to the fact that the dominant, rhyzomatous, taller, species, edified compact stands of very low species richness, in which the transition from smaller to larger scales did not permitted to many other plant species to infiltrate the community. Chrysopogon gryllus is also known for its allelopathic compounds (Djurdjević et al., 2013) with negative effects on other species' seed germination and seedlings growth, which can reduce the number of other species in the community.
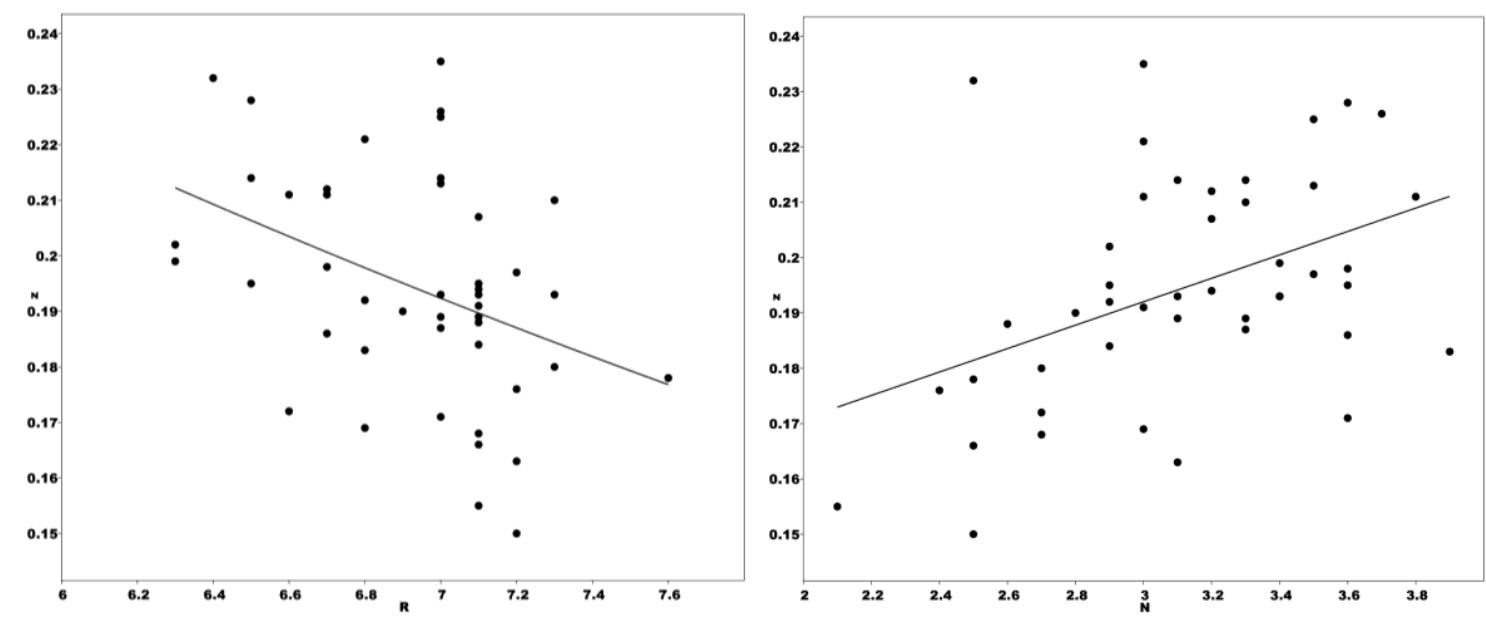

Figure 3 Relationship between $\beta$-diversity and the most important predictors ( $R$ and $N$ )

\section{Implications for conservation}

Results in this study showed that grasslands managed as meadows were richer in plant species comparing to grasslands managed as pastures and suggested that, in order to maintain dry grasslands biodiversity, a low intensity management (cutting) should be applied. Similar finding were highlighted for other regions of Romania (Turtureanu et al., 2014) or Europe (Merunková et al., 2012). Traditional techniques (cutting once per year, no fertilization) could be an effective practice for maintaining species richness and diversity, since it determines the vertical structure of grassland communities and promotes the increase in number of cutting tolerant species. Grasslands abandonment could produce modifications in plant communities floristic composition, through natural secondary successions, leading to the dominance of a few competitive, tall-grass species which suppress annual or small-sized ones and, consequently, to a decrease in plant species richness. 


\section{Conclusion}

The study provides first insights into diversity-environment relationships and their scale dependence in the xeric grasslands within Festucetalia valesiacae from NorthEastern Romania. The results showed that local environmental features and land use practices were more related to species richness while soil conditions explained a larger proportion of species richness turnover. For species richness, the heat load index was a relevant predictor for 0.01 to $100 \mathrm{~m}^{2}$ scales, with a significant negative effect and the land use (grazing when meadows and pastures were compared and abandonment when pastures and unused grasslands were compared), also with negative effect, was an important predictor but at larger scales. Mean annual precipitations, with positive effects, were important only for smaller scales. Soil nutrients was an important predictor only for $10 \mathrm{~m}^{2}$ scale. For species richness turnover, soil reaction and soil nutrients were the most important predictors. No significant differences were detected for species spatial turnover in respect to plant community type and land use. The results could offer useful suggestions if the maintaining of the floristic diversity in these xeric grasslands is desired, by highlighting the importance field management measures for eventual conservation strategies. However, further research is need to be done, with other direct measured parameters, in order to elucidate more precisely the patterns and processes driving the richness and composition of xeric grasslands from North-Eastern Romania.

Acknowledgements. Thanks are due to Ciprian Bîrsan and Loredana Mardari for the help in collecting data, to Ion Sârbu and Adrian Oprea for the help in identification of some problematic plant species and to anonymous reviewers who helped to improve the manuscript. This work was supported by POSDRU/159/1.5/S/133391 project.

\section{REFERENCES}

[1] Adler, P. B., Levine, J. M. (2007): Contrasting relationships between precipitation and species richness in space and time. - Oikos 116: 221-232.

[2] Aniţei, A., Mititelu, D. (1997): Vegetaţia pajiştilor din bazinul Bahluieţului. - Buletinul Grădinii Botanice Iaşi 6(2): 359-370.

[3] Bąba, W. (2003): Changes in structure and floristic composition of the limestone grasslands after cutting trees and shrubs and mowing. - Acta Societatis Botanicorum Poloniae 72(1): 61-69.

[4] Bartoń, K. (2014): Multi-Model Inference, Package MuMIn. [Internet]. Available from: http://cran.r-project.org/web/packages/MuMIn/index.html.

[5] Becker, T., Brändel, M. (2007): Vegetation-environment relationships in a heavy metaldry grassland complex. - Folia Geobotanica 42(1):11-28.

[6] Blaj, I. (2003): Meadow associations in the Vaslui river basin (I). - Revue Roumain de Biologie - Biologie Végétale 48(1-2): 95-104.

[7] Blaj, I. (2006): Contribution to the study of vegetation in the xerophile meadows from the river Vaslui basin. - Analele Ştiinţifice ale Universităţii „Al. I. Cuza” Iaşi 52: 83-91.

[8] Bonanomi, G., Incerti, G., Allegrezza, M. (2013): Assessing the impact of land abandonment, nitrogen enrichment and fairy-ring fungi on plant diversity of Mediterranean grasslands. - Biodiversity and Conservation 22(10): 2285-2304.

[9] Borza, A., Boşcaiu, N. (1965): Introducere în studiul covorului vegetal. - Editura Academiei Române, Bucureşti.

[10] Bouxin, G. (2005): Ginkgo, a multivariate analysis package. - Journal of Vegetation Science 16: 355-359. 
[11] Catorci, A., Cesaretti, S., Gatti, R. (2013): Effect of long-term abandonment and spring grazing on floristic and functional composition of dry grasslands in a Central Apennine farmland. - Polish Journal of Ecology 61(3): 505-518.

[12] Chiarucci, A., Viciani, D., Winter, C., Diekmann, M. (2006): Effects of productivity on species-area curves in herbaceous vegetation: evidence from experimental and observational data. - Oikos 115(3): 475-483.

[13] Chifu, T., Ştefan, N., Sârbu, I. (2000): Contributions à l'étude phytosociologique des prairies xérophiles de Moldavie (Roumanie). - Analele Ştiinţifice ale Universităţii „Al. I. Cuza" Iaşi 46: 115-126.

[14] Chifu, T., Mânzu, C., Zamfirescu, O. (2006): Flora \& Vegetaţia Moldovei (România). Editura Universităţii Alexandru Ioan Cuza, Iaşi.

[15] Ciocârlan, V. (2000): Flora ilustrată a României. - Ceres, Bucureşti.

[16] Chytrý, M., Tichý, L., Roleček, J. (2003): Local and regional patterns of species richness in Central European vegetation types along the $\mathrm{pH} /$ calcium gradient. - Folia Geobotanica 38(4): 429-442.

[17] Coldea, G., Oprea, A., Sârbu, I., Sîrbu, C, Ştefan, N. (2012): Les associations végétales de Roumanie. Tome 2. Les associations anthropogènes - Presa Universitară Clujeană, Cluj-Napoca.

[18] Cremene, C., Groza, G., Rakosy, L., Schileyko, A., Baur A., Erhardt, A., Baur B. (2005): Alterations of steppe like grasslands in Eastern Europe: a threat to regional biodiversity hotspots. - Conservation Biology 19(5): 1606-1618.

[19] De Cáceres, M., Font, X., Garcia, R., Oliva, F. (2003): VEGANA, un paquette des programas para la gestión y análisis de datos ecológicos. VII Congreso Nacional de la Asociación Española de Ecologia Terrestre: 1484-1497.

[20] De Cáceres, M., Legendre, P. (2009): Associations between species and groups of sites: indices and statistical inference. - Ecology 90(12): 3566-3574.

[21] Dengler, J. (2008): Pitfalls in small-scale species-area sampling and analysis. - Folia Geobotanica 43(3): 269-287.

[22] Dengler, J. (2009a): A flexible multi-scale approach for standardised recording of plant species richness patterns. - Ecological Indicators 9(6): 1169-1178.

[23] Dengler, J. (2009b): Which function describes the species-area relationship best? A review and empirical evaluation. - Journal of Biogeography 36(4): 728-744.

[24] Dengler, J., Becker, T., Ruprecht, E., Szabó, A., Becker, U., Beldean, M., Bița-Nicolae, C., Dolnik, C., Goia, I., Peyrat, J., Sutcliffe, L. M. E., Turtureanu P. D., Uğurlu E. (2012): Festuco-Brometea communities of the Transylvanian Plateau (Romania) - a preliminary overview on syntaxonomy, ecology, and biodiversity. - Tuexenia 32: 319-359.

[25] Dengler, J., Janišová, M., Török, P., Wellstein, C. (2014): Biodiversity of Palaearctic grasslands: a synthesis. - Agriculture Ecosystems and Environment 182(1): 1-14.

[26] De Vries, M. F., Poschlod, P., Willems, J. H. (2002): Challenges for the conservation of calcareous grasslands in northwestern Europe: integrating the requirements of flora and fauna. - Biological Conservation 104 (3): 265-273.

[27] Djurdjević, L., Gajić, G., Kostić, O., Jarić, S., Pavlović, D., Mitrović, M., Pavlović P. (2013): Allelopathic effects of Chrysopogon gryllus L. in Chrysopogonetum Pannonicum Stjep.-Ves. Steppe community at Deliblato Sands (Serbia). - Allelopathy Journal 32 (1): 133-148.

[28] Dolnik, C., Breuer, M. (2008): Scale Dependency in the species-area relationship of plant communities. - Folia Geobotanica 43(3): 305-318.

[29] Drakare, S., Lennon, J. J., Hillebrand, H. (2006): The imprint of the geographical, evolutionary and ecological context on species-area relationships. - Ecology Letters 9(2): 215-227.

[30] Dufrêne, M., Legendre, P. (1997): Species assemblages and indicator species: the need for a flexible assymmetrical approach. - Ecological Monographs 67: 345-366. 
[31] Ellenberg. H., Weber, H. E., Düll, R., Wirth, V., Werner, W., Paulißen, D. (1992): Indicator values of vascular plants in Central Europe. - Scripta Geobotanica 18: 1-258.

[32] Enyedi, Z. M., Ruprecht, E., Deák, M. (2008): Long-term effects of the abandonment of grazing on steppe-like grasslands. - Applied Vegetation Science 11(1): 55-62.

[33] Ertsen, A. C. D., Alkemade, J. R. M., Wassen, M. J. (1998): Calibrating Ellenberg indicator values for moisture, acidity, nutrient availability and salinity in the Netherlands. - Plant Ecology 135(1): 113-124.

[34] Ewald, J. (2003): The calcareous riddle: why are there so many calciphilous species in the Central European flora? - Folia Geobotanica 38(4): 357-366.

[35] Gafta, D., Mountford. O. (eds) (2008): Manual de interpretare a habitatelor Natura 2000 din România. - Risoprint, Cluj-Napoca.

[36] Giladi, I., Ziv, Y., May, F., Jeltsch, F. (2011): Scale-dependent determinants of plant species richness in a semi-arid fragmented agro-ecosystem. - Journal of Vegetation Science 22(6): 983-996.

[37] Grime, J. P. (1973): Competitive exclusion in herbaceous vegetation. - Nature 242: 344347.

[38] Hijmans, R. J., Cameron, S. E., Parra, J. L., Jones, P. G., Jarvis, A. (2005): Very high resolution interpolated climate surfaces for global land areas. - International Journal of Climatology 25: 1965-1978.

[39] Huhta, A.-P., Rautio, P. (1998): Evaluating the impacts of mowing: a case study comparing managed and abandoned meadow patches. - Annales Botanici Fennici 35: 8599.

[40] Isselstein, J., Jeangros, B., Pavlu, V. (2005): Agronomic aspects of biodiversity targeted management of temperate grasslands in Europe - a review. - Agronomy Research 3(2): 139-151.

[41] Janisová, M., Bartha, S., Kiehl, K., Dengler, J. (2011): Advances in the conservation of dry grasslands: Introduction to contributions from the seventh European Dry Grassland Meeting. - Plant Biosystems 145(3): 507-513.

[42] Janišova, M., Michalcova, D., Bacaro, G., Ghisla. A. (2014): Landscape effects on diversity of semi-natural grasslands. - Agriculture Ecosystems and Environment. 182: 47-58.

[43] Jørgensen, S. E. (2009): Ecosystem Ecology. - Academic Press, Amsterdam.

[44] Kleiber, C., Zeileis, A. (2014). Applied Econometrics with R. Package AER. [Internet]. Available from: http://cran.r-project.org/web/packages/AER/AER.pdf.html.

[45] Klimek, S., Richter-Kemmermann, A., Hofmann, M., Isselstein, J. (2007): Plant species richness and composition in managed grasslands: The relative importance of field management and environmental factors. - Biological Conservation 134(4): 559-570.

[46] Kuzemko, A. A., Becker, T., Didukh, Y. P., Ardelean, I. V., Becker, U., Beldean, M., Dolnik, C., Jeschke, M., Naqinezhad, A., Uğurlu, E., Ünal, A., Vassilev, K., Vorona, E. I., Yavorska, O. H., Dengler J. (2014): Dry grassland vegetation of Central Podolia (Ukraine) - a preliminary overview of its syntaxonomy, ecology and biodiversity. Tuexenia 34: 391-430.

[47] Löbel, S., Dengler, J., Hobohm, C. (2006): Species richness of vascular plants, bryophytes and lichens in dry grasslands: the effects of environment, landscape structure and competition. - Folia Geobotanica 41(4): 377-393.

[48] Maalouf, J.-P., Le Bagousse-Pinguet, Y., Marchand, L., Baĉhelier, E., Touzard, B., Michalet, R. (2012): Integrating climate change into calcareous grassland management. Journal of Applied Ecology 49(4): 795-802.

[49] Martin, L. M., Wilsey, B. J. (2012): Assembly history alters alpha and beta diversity, exotic-native proportions and functioning of restored prairie plant communities. Journal of Applied Ecology 49(6): 1436-1445. 
[50] Merunková, K., Preislerová, Z., Chytrý, M. (2012): White Carpathian grasslands: can local ecological factors explain their extraordinary species richness? - Preslia 84(2): 311325.

[51] Merunková, K., Preislerová, Z., Chytrý, M. (2014): Environmental drivers of species composition and richness in dry grasslands of northern and central Bohemia, Czech Republic. - Tuexenia 34: 447-466.

[52] Middleton, B. A. (2013): Rediscovering traditional vegetation management in preserves: Trading experiences between cultures and continents. - Biological Conservation 158: 271-279.

[53] Moeslund, J. E., Arge, L., Bøcher, P. K., Dalgaard, T., Ejrnæs, R., Vestergaard-Odgaard, M., Svenning, J. C. (2013): Topographically controlled soil moisture drives plant diversity patterns within grasslands. - Biodiversity and Conservation 22(10): 2151-2166.

[54] Oksanen, J., Guillaume-Blanchet, F., Kindt, R., Legendre, P., Minchin, P. R., O'Hara, R. B. (2015): Community Ecology Package. [Internet]. Available from: http://cran.rproject.org, https://github.com/vegandevs/vegan.

[55] Olsson, P. A., Mårtensson, L.-M., Bruun, H. H. (2009): Acidification of sandy grasslands - consequences for plant diversity. - Applied Vegetation Science 12(3): 350-361.

[56] Palpurina, S., Chytrý, M., Tzonev, R., Danihelka, J., Axmanová, I., Merunková, K., Duchoň, M., Karakiev, T. (2015): Patterns of fine-scale plant species richness in dry grasslands across the eastern Balkan Peninsula. - Acta Oecologica 63: 36-46.

[57] Pärtel, M. (2002): Local Plant Diversity Patterns and Evolutionary History at the Regional Scale. - Ecology 83(9): 2361-2366.

[58] Pärtel, M., Bruun, H. H., Sammul, M. (2005): Biodiversity in temperate European grasslands: origin and conservation. Proceedings of the 13th International Occasional Symposium of the European Grassland Federation, Tartu, Estonia, 29-31 August 2005. $1-14$.

[59] Pausas, J. G., Austin, M. P. (2001): Patterns of plant species richness in relation to different environments: an appraisal. - Journal of Vegetation Science 12(2): 153-166.

[60] Pykälä, J., Luoto, M., Heikkinen, R. K., Kontula, T. (2005): Plant species richness and persistence of rare plants in abandoned semi-natural grasslands in northern Europe. Basic and Applied Ecology 6(1): 25-33.

[61] R Development Core Team. (2013): R: A language and environment for statistical computing. $\mathrm{R}$ Foundation for Statistical Computing. [Internet]. Available from: http://www.r-project.org.

[62] Reitalu, T., Purschke, O., Johansson, L. J., Hall, K., Sykes, M. T., Prentice, H. C. (2012): Responses of grassland species richness to local and landscape factors depend on spatial scale and habitat specialization. - Journal of Vegetation Science 23(1): 41-51.

[63] Reitalu, T., Helm, A., Pärtel, M., Bengtsson, K., Gerhold, P., Rosén, E., Takkis, K., Znamenskiy, S., Prentice, H. C. (2014): Determinants of fine-scale plant diversity in dry calcareous grasslands within the Baltic Sea region. - Agriculture Ecosystems and Environment 182: 59-68.

[64] Ripley, B., Venables, B., Hornik, K., Gebjardt, A., Firth, D. (2015): Support Functions and Datasets for Venables and Ripley's MASS. Package MASS. [Internet]. Available from: http://cran.r-project.org/web/packages/MASS/index.

[65] Roleček, J., Čornej, I. I., Tokarjuk, A. (2014): Understanding the extreme species richness of semi-dry grasslands in east-central Europe: a comparative approach. - Preslia 86(1): 13-34.

[66] Schaffers, A. P., Sýkora, K. V. (2000): Reliability of Ellenberg indicator values for moisture, nitrogen and soil reaction: a comparison with field measurements. - Journal of Vegetation Science 11(2): 225-244.

[67] Schwabe, A., Kratochwil, A., Pignatti, S. (2007): Plant indicator values of a highphytodiversity country (Italy) and their evidence, exemplified for model areas with climatic gradients in the southern inner Alps. - Flora 202(5): 339-349. 
[68] Siefert, A., Ravenscroft, C., Althoff, D., Alvarez-Yépiz, J. C., Carter, B. E., Glennon, K. L., Mason Heberling, J., Jo, I. S., Pontes, A., Sauer, A., Willis, A., Fridley, J. D. (2012): Scale dependence of vegetation environment relationships: a meta-analysis of multivariate data. - Journal of Vegetation Science 23(5): 942-951.

[69] Sîrbu, C. (2003): Podgoriile Cotnari, Iaşi şi Huşi - studiu botanic. - Editura Ion Ionescu de la Brad, Iaşi.

[70] Turtureanu, P. D., Palpurina, S., Becker, T., Dolnik, C., Ruprecht, E., Sutcliffe, L. M. E., Szabó, A., Dengler, J. (2014): Scale- and taxon-dependent biodiversity patterns of dry grassland vegetation in Transylvania (Romania). - Agriculture Ecosystems and Environment 182: 15-24.

[71] Zulka, K. P., Abensperg-Trauna, M., Milasowszkya, N., Bieringerd, G., Gereben-Krenna, B. A., Holzingere, W., Hölzler, G., Rabitsch, W., Reischütz, A., Querner, P., Sauberer, N., Schmitzberger, I., Willner, W., Wrbka, T., Zechmeister, H. (2014): Species richness in dry grassland patches of eastern Austria: A multi-taxon study on the role of local, landscape and habitat quality variables. - Agriculture Ecosystems and Environment 182: 25-36.

[72] Wamelink, G. W. W., Joosten, V., van Dobben, H. F., Berendse, F. (2002): Validity of Ellenberg indicator values judged from physico-chemical field measurements. - Journal of Vegetation Science 13(2): 269-278.

[73] Wanner, A., Suchrow, S., Kiehl, K., Meyer, W., Pohlmann, N., Stock, M., Jensen, K. (2014): Scale matters: Impact of management regime on plant species richness and vegetation type diversity in Wadden Sea salt marshes. - Agriculture Ecosystems and Environment 182: 69-79.

[74] Wilson, J. B., Peet, R. K., Dengler, J., Pärtel, M. (2012): Plant species richness: the world records. - Journal of Vegetation Science 23(4): 796-802.

[75] Habitats Directive 92/43/EEC on the conservation of natural habitats and of wild fauna and flora. [Internet]. 1992. [Cited 2015 Jan 30]. Available from: http://ec.europa.eu/environment/nature/legislation/habitatsdirective/index_en.htm.

\section{ELECTRONIC APPENDIX}

This article has electronic appendices. 